\title{
Development of Artificial Substitutes for Upper Digestive Tract: Personal Experience of Trials and Errors
}

\author{
Eun-Jae Chung \\ Department of Otorhinolaryngology-Head and Neck Surgery, Seoul National University College of Medicine, Seoul, Korea
}

인공장기를 이용한 구강·인두·식도의 재건: 연구의 경험과 한계

정 은 재

서울대학교 의과대학 이비인후과학교실

\author{
Received September 8, 2019 \\ Revised December 9, 2019 \\ Accepted December 9, 2019 \\ Address for correspondence \\ Eun-Jae Chung, MD, PhD \\ Department of Otorhinolaryngology- \\ Head and Neck Surgery, \\ Seoul National University \\ College of Medicine, \\ Seoul National University Hospital, \\ 101 Daehak-ro, Jongno-gu, \\ Seoul 03080, Korea \\ Tel +82-2-2072-0215 \\ Fax $+82-2-745-2387$ \\ E-mail voicechung@snu.ac.kr
}

\begin{abstract}
The current treatments for esophageal diseases, such as carcinomas, trauma or congenital malformations, require surgical intervention, and esophageal reconstruction using redundant parts of the gastrointestinal tract. However, the use of gastrointestinal segments can cause various surgical morbidities and mortality because additional abdominal surgery may be required at the expense of other anatomic structures. Therefore, tissue engineering using various biomaterial or cell sources has emerged as an alternative strategy of biomimicking the native esophageal tissue that could be implanted as an artificial graft. Although tissue engineering techniques have promise as an effective regenerative strategy, no functional solution currently exists for esophageal reconstruction. Here, we present a review of the progress made in the field of regenerative medicine for esophageal reconstruction based on the personal experience. Korean J Otorhinolaryngol-Head Neck Surg 2019;62(12):675-80
\end{abstract}

Key Words Epithelial cell · Esophagus · Smooth muscle cell · Tissue engineering · Tissue scaffolds.

\section{서 론}

구강, 인두, 식도 등을 포함하는 일련의 소화기관을 상부소 화기라고 한다. 소장과 대장 등의 하부소화기는 잘 알려진 바 와 같이 장기 전체의 길이가 매우 길어, 악성 종양 등의 치료 를 위해 장기의 일부를 제거하더라도 남아 있는 정상조직을 이용하여 재건하는 것이 표준 치료이고 동일한 자신의 장기 부위를 사용하므로 기능적으로도 최선의 결과를 얻는 것이 가능하다. 이에 반하여 상부소화기는 장기의 길이가 하부소 화기처럼 길지 않고 따라서 장기의 일부를 제거하는 경우 남 은 장기를 이용하여 재건하는 데 한계가 생긴다. 따라서, 구 강 및 인두의 재건은 신체 다른 부위의 조직을 이용하는 유리

This is an Open Access article distributed under the terms of the Creative Commons Attribution Non-Commercial License (https://creativecommons.org/licenses/by-nc/4.0) which permits unrestricted non-commercial use, distribution, and reproduction in any medium, provided the original work is properly cited. 피판(free flap)이나 유경 피판(pedicled flap) 등을 이용하게 되고 식도는 위(stomach)를 식도의 형태로 만들어 남아 있는 식도조직과 연결하는 방법을 주로 사용하게 된다. ${ }^{1,2}$

또 하나의 매우 특징적인 점은, 사람과 같은 고등동물에서 는 호흡과 삼킴 작용이 분리되어 있고 호흡과 삼킴을 동시에 하는 것이 아니라 호흡하는 동안에는 호흡과 관련된 후두가 열리고 뒤쪽의 식도 입구 부위는 닫히며, 삼킴 과정이 시작되 면 반대로 후두는 닫히고 식도 입구 부위는 열리면서 호흡 튜 브는 막히고 삼킴 튜브만이 열리면서 음식의 안전한 이동이 가능해진다는 점이다. 식도 내로 이동한 음식은 식도의 연동 운동을 통하여 위로 이동하게 되는데 식도는 평상시에는 내 강이 거의 닫혀 있고 음식이 유입되어 팽창하고 연동운동으 로 진행하면서 순차적 팽창과 수축을 진행하게 된다는 또 하 나의 특유의 성질을 가지고 있다. ${ }^{3,4)}$ 이러한 연동운동의 중요 성은 사람과 같은 직립개체가 아닌 동물 실험에서 더욱 분명 
해지는데 인두나 식도 전장을 제거하고(circumferential defect) 인위적으로 재건하는 경우 사람에서는 연동운동이 불 가능한 전완 유리 피판(radial forearm free flap)이나 전외측 대퇴부 피판(anterolateral thigh free flap)을 튜브 형태로 재건하여도 중력에 의해 음식물의 진행이 가능하지만, 대부 분의 동물에서는 중력에 의한 이동이 미미해지므로, 식도의 전결손을 인공지지체로 재건하였을 때 중력의 도움을 받지 않은 채 연동운동만으로 음식물을 이동시켜야 한다. 이러한 기능적 재생은 아직까지 해결하기 매우 어려운 난제이다. 인 두, 식도 이외의 상부소화기에서 역시 점막층 외부의 근육층 에서의 수축에 의한 강한 힘이 삼킴 작용 시 닫혀 있던 식도 입구 부위를 통과해주게 하는 중요한 요인이 되므로 호흡과 조화로운 과정에 의한 근육수축이 정확히 일어나야 안전하고 정상적인 구강을 통한 식사가 가능하다.

조직공학을 이용한 인공장기를 이식하는 측면에서 또 다른 핵심은, 식도에서는 물론이고 구강과 인두 등의 상부소화기에 서는 외부의 세균 등 미생물과 음식물, 위산, 소화효소, 타액 등의 조직의 감염과 괴사 등의 심각한 문제를 유발하는 물질 들과 내부공간은 상피 및 근육층에 의해 분리되어 있는데, 수 술 등으로 인하여 이러한 무균공간과 오염공간이 서로 연결 되게 되면 임상적으로 우리가 경험하는 누공에 의한 조직 감 염 및 패혈증, 경동맥 파열 등의 위험이 발생하게 된다. 따라 서, 이러한 오염환경에서 이식된 인공지지체를 생존시켜야 하 는 핵심 기술이 필요하다.,5)

\section{인공장기를 이용한 구강-인두·식도 재건 기술 개발의 필요성}

잘 알려진 바와 같이 식도암을 포함한 두경부암의 임상 수 요는 해마다 증가하고 있으며, 이에 따른 의료비 역시 지속적 으로 증가하고 있다. 언급한 바와 같이 구강, 인두, 식도 등에 서 광범위 절제술을 시행하는 경우 다른 신체 부위로부터의 자가조직 이식이 필수적이다. 현재까지의 방법 중 기능적으로 가장 우수한 것은 구강 및 인두암의 경우 유리 피판(free flap) 이며 식도암의 경우 위(stomach)를 끌어올려 재건하는 방법 등이다. 이러한 모든 재건 방법은 우수한 수술 성공률로 현재 의 표준 치료로 자리잡았으나 재건을 위한 추가 수술이 필요 하다는 점과 추가 수술에 의한 합병증, 사회·경제적 손실, 환 자 및 의료진의 물리적·심리적 부담이라는 문제가 있다.) 따 라서, 조직공학적 방법을 통한 재건 방법의 개발을 통해 이러 한 문제를 해결할 수 있고 미래 의료산업 선도를 위한 핵심 원천 기술의 하나가 될 것으로 기대하고 있다.

\section{인공장기를 이용한 구강-인두·식도 재건 연구를 위한 동물모델}

저자의 연구는 인공식도로부터 시작되었는데 ${ }^{8-12)}$ 두경부외 과의로서 임상적 전문성이 다소 부족한 흥부외과영역의 인공 식도라는 다소 생소한 연구를 시작한 이유는 구강, 인두 등의 세부 영역에서 조직공학을 이용한 재건 동물모델의 문제가 있었기 때문이었다. 즉, 가장 쉽게 진행할 수 있는 rat 등의 소 동물을 이용한 연구는 구강과 인두의 수술적 제거는 물론이 거니와 지지체를 이식하는 작업 자체가 매우 어렵다. 반면, 경 부식도는 경부절개를 통해 손쉽게 접근할 수 있고, 상부소화 기는 모두 동일한 형태와 유사한 기능적 측면에 있어 동일하 게 적용할 수 있는 모델이면서 가장 현실적인 동물모델이기 때문이었다.

현재까지 다양한 식도 재건의 동물모델이 발표되었는데, 설 치류, ${ }^{13)}$ 비글 ${ }^{14,15)}$ 돼지 ${ }^{16)}$ 등의 동물모델에서 인공식도 이식연 구가 진행되었다. 점막만을 제거하는 부분결손과 달리 점막 및 근육층을 모두 제거하는 전층결손, 이 중에서도 $360^{\circ}$ 전결 손이 가장 쉽지 않은 모델이다. 이러한 모델은 돼지, ${ }^{17)}$ 비글(8) 등에서 보고되었다. 그러나, 두경부 외과의사로서 잘 알고 있 는 것처럼, 이러한 모델에서도 역시 넘어야 할 문제들이 많은 데, 첫 번째로 이식 수술 후 일정 기간 동안의 금식을 시키는 문제였다. 사람을 대상으로 한 두경부암 수술의 경우 창상의 안정적 치유를 위하여 적어도 1주간의 비위관(nasogastric tube)을 통한 영양공급과 구강식에 제한이 반드시 필요함은 주지의 사실이다. 이것은 구강, 인두, 식도 등의 내부에 세균, 소화효소, 타액은 물론 음식물과 이에 의한 압력, 삼킴 작용 및 연동운동과 관련된 수많은 근육들의 수축에 의한 압력 등 일반적 장기와 다른 환경에서 안정적인 wound healing process가 일어나야 하기 때문이고 어떠한 이유에서건 문합부의 불완전한 창상치유로 누공(fistula)이 발생하면 많은 문제가 발생하기 때문이다. ${ }^{19}$ Beagle 등의 대동물에서 비경구 영양 공급은 사람에서처럼 혈관 루트를 통해 일정 기간 가능하지 만, ${ }^{15,18)}$ 가장 손쉽고 반복적 이식 실험이 가능한 rat(adult)의 경우 현재까지도 확립된 방법이 없는데 ${ }^{20,21)}$ 그 이유는 rat (adult)의 습성 때문이다. Rat은 체외로 어떠한 외부장치를 하더라도 자신의 이빨을 이용해서 망가트릴 수 있는 능력을 가지고 있는데, rat의 머리와 앞다리를 이용하면 신체 거의 모 든 부위에 닿을 수 있고 그 어떤 불편한 장치도 가만히 두지 않기 때문이었다. 아직까지 저자의 최선은 Fig. 1과 같은 방법 의 고안인데 이 방법은 1) rat의 이빨이 닿지 않는 거의 유일 한 부위가 머리 뒤쪽, 양측 귀 사이 공간인 것, 2) stomach에 연결한 gastrostomy tube를 피하터널을 통해 양측 귀 사이 


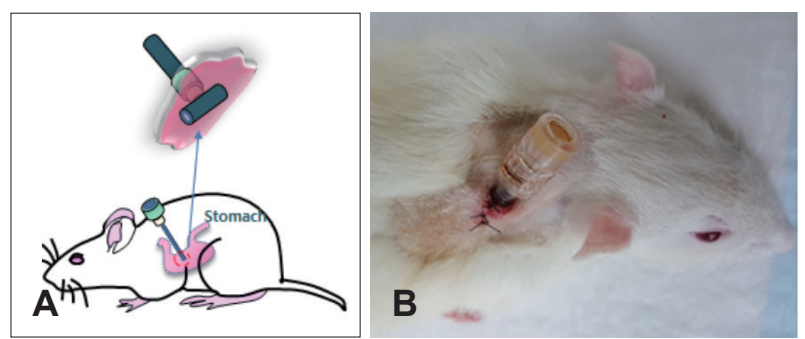

Fig. 1. Modified gastrostomy technique. A puncture hole is made in the middle of the stomach and T-tube was inserted (A). The end of tube is fixed behind the ear (B).

공간으로 빼내는 것, 3) 주입한 영양공급 물질-저자는 상품 화된 그린비아 등의 고칼로리 상품을 주로 사용하였다—이 역 류하여 투입이 제대로 되지 않는 것을 예방하고 안정적인 영 양공급이 가능하도록 빼낸 튜브의 끝에 정맥주사 사용 시 이 용하는 heparin cap을 사용한 것이다.

그러나, 이러한 장치의 적용에도 아직까지 시행하였던 모든 $360^{\circ}$ circumferential defect 재건에 있어 비록 전술한 modified gastrostomy를 이용한 영양공급을 시행하지 않고 구강 식이를 진행하는 경우 많은 경우에서 1주째 사망하였고, 고 안된 영양공급 장치를 이용하는 경우에는 더 오래 생존은 하 였지만, 이 경우 역시 3주 이상을 넘기지 못하였다. 이것은 비 단 영양공급 루트의 문제가 아닌, 얼마나 실제 생체조직과 유 사하게 기능적으로 지지체 내 조직이 재생되느냐의 문제라고 생각되는데, in vitro에서 아무리 정상조직과 유사한 물리적 성질을 가지도록 제작된다고 하여도 실제 이식된 후 재생된 조직이 정상조직과 유사한 성질이 적어질수록 collapse와 expansion, 연동운동을 지속적으로 반복해야하는 식도 본연 의 조직의 특성을 재현하기 어렵고 rat과 같은 $2 \mathrm{~mm}$ 직경의 식도 circumferential defect를 재생함에 있어 이식 부위에서 음식물에 의한 complete obstruction과 이에 의한 2차적 rupture를 피하기가 어렵다는 문제가 있다. 여기에는 동물의 습성 역시 작용하는데, rat은 자신의 털을 계속 핝아 주는 grooming의 본능이 있고 이에 따라 rat hair 역시 hair ball의 뭉친 형태로 함께 삼켜지게 된다. 경구식이를 금지시켜도 이러한 grooming은 막을 방법이 없으므로 일정 기간까지 매우 건강 하게 회복되다가도 어느 순간 갑작스레 상태가 나빠지기 시 작함을 흔하게 경험할 수 있었다. 따라서, 향후 이러한 문제 를 해결할 수 있는 이식 소재의 혁신적 보완과 정상과 가장 가깝게 조직을 재생시켜야 하는 과제가 반드시 해결되어야 임상에 다가서게 될 것이다.

Beagle 등의 대동물에서 저자는 사람처럼 정맥주사 루트 를 확보한 후 이를 통해 이식 2주 후까지 total parenteral nutririon을 시행하였고 적용이 가능하였다. 따라서, 대동물의 경우 이식 후 경구식이 제한 및 비경구적 영양공급의 문제는
해결하기 상대적으로 훨씬 수월하나 대동물 실험의 맹점은 무엇보다 연구를 위해 소요되는 경비가 비교되지 않을 정도 로 고가이고, 관리 및 평가 역시 훨씬 더 많은 규모의 연구비 와 인력, 절차 등이 소요되므로 다수의 개체로 실험하는 것 이다.

\section{구강·인두·식도 인공장기 소재}

모든 인공지지체에 적용되는 사항이지만, 기본적이고 필수 적인 지지체의 조건인 호스트 세포에 독성이 없고, 적절한 재 생과 분해, 또한 호스트 세포의 최적의 생착환경 및 최소한 의 염증반응 등이 필요하며, 상부소화기의 경우 이에 더불어, 특수환경인 타액, 세균, 위산, 소화효소, 음식 등의 오염환경 에서 재생된 조직이 생존해야 하며, 호흡과 삼킴 작용이 조 화롭게 이루어져야 한다는 점, 순차적인 연동운동이 이루어 져야 한다는 특성이 있다. ${ }^{5}$

이러한 상부소화기 인공장기를 위한 소재로 천연소재와 인 공합성물질 등이 사용되어 왔다. 천연소재는 collagen, silk, gelatin 등의 단백질 기반의 소재, chitosan, cellulose 등의 polyssacharide 기반 소재와 decellurlized extracellular matrix(ECM) 기반의 소재 등이 있다. 이러한 천연소재, 특히 decellurlized ECM은 본연의 biomechanical properties와 surface topography를 유지하므로 가장 이상적이나, 지속적 인 연동운동, 압력, 물리적 및 화학적 등에 대한 기계적 성질 이 약한 단점이 있다. 인공합성물질은 비교적 저렴한 비용으 로 대량 생산이 가능하다는 등의 장점이 있다.5)

저자의 첫 번째 연구는 ${ }^{8)}$ 2013년에 시작되었는데, basic research의 기반이 없었고 임상적 need가 반영된 연구를 하고 싶었던 저자는 당시 이미 충분한 기반을 가지고 계셨던 한림 대 박찬흠 교수의 도움으로 연구를 시작하였다. 첫 실험의 핵 심은 소재에 관한 것이었고, 인공합성물이 아닌 천연재료인 실크 소재로 rat $360^{\circ}$ circumferential defect를 위한 인공지 지체를 개발하고 이를 이식하는 실험을 진행하였다. 당시에는 첫 번째 실험이고 rat을 이용한 식도전 결손 실험은 국내에서 는 최초였기 때문에 어떤 일이 일어나는지를 시행착오를 통해 서 알 수 있었고 앞서 기술한 동물실험 기법의 문제가 해결되 어야 함을 체험하게 되었다. 지지체 이식 후 2주째 상피층이 재생되는 결과를 얻을 수 있었다.

\section{생체 내 바이오리액터 (Omentum Culture)의 적용}

첫 번째 실험 결과에서 얻은 교훈은, 임상의로서 당연히 가 
지는 질문으로 "과연 circulation이 없는 인공조직을 식도와 같은 오염환경에 이식한다고 제대로 생존할까?” 하는 근본적 회의였다. 물론, 첫 실험에서 상피재생의 확인과 지지체를 통 한 조직재생과 육안적 식도 결손의 복원이라는 성과를 얻었 으나, 모두 조기에 폐사하였으므로 개선이 필요하였다. 따라 서, "지지체 내 조직을 어느 정도 만들어 이식하면 어떨까?" 하는 개념으로 omentum에 2주간 이식한 후 다시 꺼내 식도 결손 부위에 이식하는 방법을 적용하였다.

본래의 omentum culture를 통한 조직배양과 이식은 pedicled omental flap의 개념으로 이식된 지지체를 omentum에 싸고, omentum으로 가는 혈류는 그대로 보존한 채 배양하 는 개념이지만,22,23) 저자의 타겟 장기는 흥부나 복부가 아니라 경부식도였기 때문에 2주간 배양 후 꺼내서 이식하는 방법으 로 변형하여 시행하였다. Omentum 이식 2주 후 지지체 내부 와 주변으로의 자가조직 및 신생혈관 재생을 확인하였고, 배 양된 지지체를 이식한 결과 상피층 재생은 역시 성공적이었 으나 근육층의 재생과 조기 폐사의 문제는 여전히 풀어야 할 숙제였다.

\section{맞춤형 바이오리액터의 제작 ${ }^{10-122}$}

2015년에 저자는 근무지를 서울대병원으로 이동할 기회를 가지게 되었고, 본 교실의 권성근 교수의 도움으로 연구를 지 속하여 시작할 수 있게 되었다.

식도 본연의 기능적 특성으로 무엇보다 순차적인 연동운동 이 있고, 평소에는 collapse되었다가 음식이 들어오는 삼킴과 정의 진행과 함께 상부식도 괄약근이 열리고 연동운동에 의 해 음식물이 진행되는 특징이 있다. 이 과정에서 유입된 음식 물의 압력과 근육에 의한 순차적 수축 등의 특이적 생체 내 환경을 이식된 지지체에 학습시키는 것이 필요하고 그동안의 trial과 error를 바탕으로 저자는 인제대 신정욱 교수팀과 공 동으로 최적의 인공식도 배양을 위한 맞춤형 바이오리액터 환경을 탐색하고 적용하는 연구를 진행하였다.

일련의 연구에서, 식도 특유의 최적 배양환경 탐색 연구를 위해, 줄기세포의 식도상피세포로의 분화를 위한 환경 연구 를 진행하였고 flow-induced shear stresses보다는 $50 \mathrm{~mm} \mathrm{Hg}$ 에서의 intermittent hydrostatic pressures가 더욱 효과적인 바이오리액터 mechanical force였고, $5 \mu \mathrm{M}$ 농도의 all-trans retinoic acid가 상피세포로의 분화에 가장 효과적인 biochemical reagent concentration이었음을 확인하였다.11)

또한, in vitro 연구로 실제 식도와 유사한 다층구조(이중 층)를 가지는 지지체 형태로 제작된 환경에서 줄기세포의 내 부 상피층과 외부 근육층으로의 분화를 유도하는 실험을 진
행하였는데, 이를 위하여 내부와 외부의 다른 형태의 자극을 동시에 바이오리액터 환경에서 만들어 줄기세포의 내측 상피 및 외측 근육세포로의 분화에 더욱 유리한 환경을 도출하였 고 이때 발현되는 상피세포의 마커는 바깥층보다 내부층에 유의하게 증가하였고 근육세포 마커는 바깥층에 유의하게 증 가하여 내부와 외부로의 각기 다른 상피와 근육세포로의 분 화에 성공하였다. ${ }^{12}$

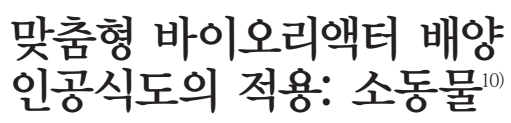

이러한 연구 결과를 기반으로 이중층의 전기방사 기반의 튜브형태의 인공지지체에 물리적 성질 강화를 위한 추가적인 3D printing 외부층을 가지는 식도 $360^{\circ}$ circumferential defect 재건을 위한 소동물 실험을 진행하였다. ${ }^{10)}$ 이전 동물모델 의 경험을 바탕으로 앞서 기술한 modified gastrostomy technique을 적용하였고, 이식 전 지지체 내 성체줄기세포를 고안 된 바이오리액터 환경에서 배양한 후 실험을 진행하였다. 본 실험에서 이전과 다른 결과들이 도출되기 시작하였는데, 1) 정상 상피층과 거의 동일한 형태의 상피층 재생과 2) 완벽하 지는 않지만 이전결과에서 얻을 수 없었던 상당한 수준의 근 육층 재생, 3) 이식된 개체의 의미 있게 향상된 경구식이섭취 능력(이식 후 3일째부터 gastrostomy feeding과 경구섭취 병 행)과 체중 유지, 정상적인 activity 유지 등의 고무적인 맞춤 형 바이오리액터 배양 그룹과 생체 내 바이오리액터인 omentum 배양 그룹에서 확인하였다.

\section{맞춤형 바이오리액터 배양 인공식도의 적용: 대동물}

다음 단계로 시행한 것은 beagle과 같은 대동물에서의 적 용이었고 이는 임상으로 가는 전 임상 단계에서 매우 중요한 과정이다. 본 연구는 약 $5 \times 3 \mathrm{~cm}$ 크기의 경부식도 결손을 만 든 후 식도조직재생을 위한 맞춤형 바이오리액터 환경에서 배양된 줄기세포를 포함한 전기방사 지지체를 조직 결손 부위 에 이식하는 방법으로 진행되었다. 지지체는 실제 식도 미세 구조를 모사하기 위하여 내측과 외측을 각기 다른 형태의 나 노 구조로 전기방사하였고 이전 연구에서 도출한 줄기세포로 부터 내측 상피세포와 외측 근육세포로 분화시키는 최적의 환경에서 배양되었다. 이식 후 특별한 합병증 없이 정상적으 로 회복되었고, 수술 후 1 달째 시행한 내시경 검사에서 정상 조직과 구별이 어려울 정도의 육안적 조직재생을 확인하였다. 이식 후 6 개월과 12 개월 후 조직을 적출하여 전자현미경을 
통한 점막재생과 조직학적 분석을 통한 상피층과 근육층의 재생, $\mathrm{CT}$ 검사를 통한 구조적 평가에서 모두 정상식도조직 과 거의 동일한 형태의 재생된 조직을 확인할 수 있었다.

\section{현재의 한계 및 향후 연구 방향}

언젠가 두경부암 free flap 수술 중 계속되는 과도한 업무 에 지친 전공의 선생님의 이야기가 아직도 생각나는데, 암을 제거하고 재건을 위해 공여 부위 수술을 시작할 때 "선생님, 저희가 20년 후에도 이런 수술을 계속하고 있을까요?”라고 물어보았던 기억이 있다. 저자가 어릴 때 휴대폰으로 인터넷 을 하고, 인터넷 환경이 세상을 이렇게 바꾸어 놓을지는 상상 도 하기 어려웠던 일이었고, 인공지능이 우리의 생활의 전면 에 등장하고 삶의 모든 부분이 하루가 다르게 바뀌는 현재, 앞으로는 free flap 수술이 없어질 날이 올 것이 충분히 가능 하다고 생각한다. 그러나, 아직까지 vascularized 자가조직을 대체할 만한 상부소화기 결손 복원 방법은 존재하지 않고, 그 연구 역시 여러 한계로 임상에 다가서지 못하고 있다.

현재까지 submucosal resection 등의 전층 결손이 아닌 부 분층 결손에서는 실제 임상에서 조직공학적으로 만들어진 지지체가 성공적으로 이식된 보고들이 상당수있다. ${ }^{2024-27)}$ 그 러나, 실패할 경우 수술 후 합병증과 위험도가 매우 높은 전 층 결손 복원을 위한 임상 적용 사례는 극히 드물고, 2016년 Lancet지에 stent와 extracellular matrix를 이용하여 large esophageal defect에 대하여 세계 최초로 in-vivo esophageal regeneration을 보고한 문헌이 있는 정도이다. ${ }^{28)}$ 비록, 스 텐트를 제거한 후 상피세포의 층구조 재생 및 연동운동 재 생, 4년 후까지 정상적으로 환자가 식사하고 제충을 유지함을 보고하였으나 circumferential total defect가 아닌 partial defect에서의 적용이었다. 아직까지 publish되지는 않았으나 circumferential total defect의 임상 적용은 2017년 Fabio Triolo, Saverio la Francesca 두 명의 이탈리아 의사가 75세 미국 환자에게 세계 최초로 인공식도를 이식하였다고 뉴스 를 통해 보고된 것을 찾을 수 있었는데, 이들이 사용한 방법 은 저자의 최근 연구 방법인 식도의 in vivo 환경에 최적화 배 양 시킨 줄기세포와 함께 이식하는 것과 동일한 방법이었고 현재 수술 후 결과에 대한 보고는 찾을 수 없으며 빠른 시간 내에 보고될 것으로 생각된다.

저자의 개인적 경험을 바탕으로 임상으로 진입하기 위하여 반드시 넘어서야 할 한계를 정리해 보면 다음과 같다. 1) 인 공지지체 내로의 early vascularization 및 조기조직재생으로 구강, 인두, 식도 등의 오염환경에서 지지체 내로의 early vascularization은 이식된 지지체와 재생되는 조직의 생존을 위
해 필수적이다. 일반적인 무균환경과 다른 감염 조건에서 이 러한 명제를 만족시킬 수 있는 해법을 찾기 위하여 수많은 연 구자들이 매달려 연구를 진행하고 있고 저자 역시 여러 공동 연구자분들과 나름의 해법을 찾기 위해 노력하고 있다. 2) 상 부소화기 특유의 물리적 조직 특성이 반영되어야 한다는 점 인데 기술한 바와 같이, 실제 임상에서도 구강-인두·식도 등 의 세균, 음식물, 소화효소, 연동운동, 음식물에 의한 압력이 가해지는 특수환경에서의 인공지지체의 물리적 특성 개선을 위한 소재의 발굴 및 보완, 다양한 약물의 지지체 내 탑재와 적절한 방출은 물론 근본적인 개념 자체의 변화 등이 필요하 다 하겠다.

\section{Acknowledgments}

This research was supported by the Basic Science Research Program through the National Research Foundation of Korea (NRF) funded by the Ministry of Education (2017R1C1B2011132) and grant no 03-2017-0270 from the SNUH research fund.

\section{ORCID}

Eun-Jae Chung

https://orcid.org/0000-0003-3918-7717

\section{REFERENCES}

1) Poghosyan T, Gaujoux S, Sfeir R, Larghero J, Cattan P. Bioartificial oesophagus in the era of tissue engineering. J Pediatr Gastroenterol Nutr 2011;52 Suppl 1:S16-7.

2) Shen Q, Shi P, Gao M, Yu X, Liu Y, Luo L, et al. Progress on materials and scaffold fabrications applied to esophageal tissue engineering. Mater Sci Eng C Mater Biol Appl 2013;33(4):1860-6.

3) Skandalakis JE, Ellis H. Embryologic and anatomic basis of esophageal surgery. Surg Clin North Am 2000;80(1):85-155.

4) Londono R, Badylak SF. Regenerative medicine strategies for esophageal repair. Tissue Eng Part B Rev 2015;21(4):393-410.

5) Chung EJ. Bioartificial esophagus: Where are we now? Adv Exp Med Biol 2018;1064:313-32.

6) Maghsoudlou P, Eaton S, De Coppi P. Tissue engineering of the esophagus. Semin Pediatr Surg 2014;23(3):127-34.

7) Tan JY, Chua CK, Leong KF, Chian KS, Leong WS, Tan LP. Esophageal tissue engineering: An in-depth review on scaffold design. Biotechnol Bioeng 2012;109(1):1-15.

8) Chung EJ, Ju HW, Park HJ, Park CH. Three-layered scaffolds for artificial esophagus using poly( $\varepsilon$-caprolactone) nanofibers and silk fibroin: An experimental study in a rat model. J Biomed Mater Res A 2015;103(6):2057-65.

9) Chung EJ, Ju HW, Yeon YK, Lee JS, Lee YJ, Seo YB, et al. Development of an omentum-cultured oesophageal scaffold reinforced by a 3D-printed ring: Feasibility of an in vivo bioreactor. Artif Cells Nanomed Biotechnol 2018;46(sup1):885-95.

10) Kim IG, Wu Y, Park SA, Cho H, Choi JJ, Kwon SK, et al. Tissueengineered esophagus via bioreactor cultivation for circumferential esophageal reconstruction. Tissue Eng Part A 2019;25(21-22):147892.

11) Wu Y, Kang YG, Cho H, Kim IG, Chung EJ, Shin JW. Combinational effects of mechanical forces and substrate surface characteristics on esophageal epithelial differentiation. J Biomed Mater Res A 2019;107(3):552-60.

12) Wu Y, Kang YG, Kim IG, Kim JE, Lee EJ, Chung EJ, et al. Mechanical stimuli enhance simultaneous differentiation into esophageal cell 
lineages in a double-layered tubular scaffold. J Tissue Eng Regen Med 2019;13(8):1394-405.

13) Nieponice A, Gilbert TW, Johnson SA, Turner NJ, Badylak SF. Bone marrow-derived cells participate in the long-term remodeling in a mouse model of esophageal reconstruction. J Surg Res 2013; 182(1):e1-7.

14) Nieponice A, McGrath K, Qureshi I, Beckman EJ, Luketich JD, Gilbert TW, et al. An extracellular matrix scaffold for esophageal stricture prevention after circumferential EMR. Gastrointest Endosc 2009;69(2):289-96.

15) Badylak SF, Vorp DA, Spievack AR, Simmons-Byrd A, Hanke J, Freytes DO, et al. Esophageal reconstruction with ECM and muscle tissue in a dog model. J Surg Res 2005;128(1):87-97.

16) Farrell TM, Archer SB, Metreveli RE, Smith CD, Hunter JG. Resection and advancement of esophageal mucosa. A potential therapy for Barrett's esophagus. Surg Endosc 2001;15(9):937-41.

17) Jönsson L, Friberg LG, Gatzinsky V, Jennische E, Sandin A, Abrahamsson K. Early regenerative response in the intrathoracic porcine esophagus-the impact of the inflammation. Artif Organs 2014;38(6):439-46.

18) Badylak S, Meurling S, Chen M, Spievack A, Simmons-Byrd A. Resorbable bioscaffold for esophageal repair in a dog model. J Pediatr Surg 2000;35(7):1097-103.

19) Zhang L, Li N, des Robert C, Fang M, Liboni K, McMahon R, et al. Lactobacillus rhamnosus GG decreases lipopolysaccharide-induced systemic inflammation in a gastrostomy-fed infant rat model. J Pediatr Gastroenterol Nutr 2006;42(5):545-52.

20) Nieponice A, Ciotola FF, Nachman F, Jobe BA, Hoppo T, Londono $\mathrm{R}$, et al. Patch esophagoplasty: Esophageal reconstruction using biologic scaffolds. Ann Thorac Surg 2014;97(1):283-8.
21) Kuppan P, Sethuraman S, Krishnan UM. Tissue engineering interventions for esophageal disorders--promises and challenges. Biotechnol Adv 2012;30(6):1481-92.

22) Li J, Xu P, Chen H, Yang Z, Zhang Q. Improvement of tracheal autograft survival with transplantation into the greater omentum. Ann Thorac Surg 1995;60(6):1592-6.

23) Li J, Xu P, Chen H. Successful tracheal autotransplantation with two-stage approach using the greater omentum. Ann Thorac Surg 1997;64(1):199-202.

24) Badylak SF, Hoppo T, Nieponice A, Gilbert TW, Davison JM, Jobe BA. Esophageal preservation in five male patients after endoscopic inner-layer circumferential resection in the setting of superficial cancer: A regenerative medicine approach with a biologic scaffold. Tissue Eng Part A 2011;17(11-12):1643-50.

25) Hoppo T, Badylak SF, Jobe BA. A novel esophageal-preserving approach to treat high-grade dysplasia and superficial adenocarcinoma in the presence of chronic gastroesophageal reflux disease. World $\mathbf{J}$ Surg 2012;36(10):2390-3.

26) Ohki T, Yamato M, Murakami D, Takagi R, Yang J, Namiki H, et al. Treatment of oesophageal ulcerations using endoscopic transplantation of tissue-engineered autologous oral mucosal epithelial cell sheets in a canine model. Gut 2006;55(12):1704-10.

27) Takagi R, Murakami D, Kondo M, Ohki T, Sasaki R, Mizutani M, et al. Fabrication of human oral mucosal epithelial cell sheets for treatment of esophageal ulceration by endoscopic submucosal dissection. Gastrointest Endosc 2010;72(6):1253-9.

28) Dua KS, Hogan WJ, Aadam AA, Gasparri M. In-vivo oesophageal regeneration in a human being by use of a non-biological scaffold and extracellular matrix. Lancet 2016;388(10039):55-61.

\section{정답 및 해설}

(4)

해 설 위 증례는 경부에 발생하는 박동성 종괴로, 위치상 총경동맥이 분지하는 부위에서 내경동맥과 외경동맥을 분리시키면서 커 져있으므로 경동맥소체종양으로 진단할 수 있다. (1) Catecholamine을 분비하는 종양인 pheochromocytoma가 동반될 수 있는 thyroid medullary carcinoma의 경우 체크하여야 한다. (2) 답가지는 schwannoma에서 보이는 소견이다. (3) 내경동 맥을 내측으로 외경동맥은 외측으로 전위시킨다. (5) 새열기형낭종이나 갑상설관낭종에 대한 설명이다. 참고 문헌: 대한이비인후과학회. 이비인후과학-두경부외과학(개정판). 서울: 일조각;2009. p.1769-70. 